\title{
INVESTIGATION ON THE ENVIROMENTAL EFFECT OF LOCAL PRODUCTION METHOD OF ALUMINIUM UTENSIL IN KANO
}

\author{
${ }^{1}$ Yakubu, Y. I. and ${ }^{2}$ Yola, I. A. \\ ${ }^{1}$ Ajaokuta Steel Company Limited, Steel City, Ajaokuta, Kogi State, Nigeria. \\ ${ }^{2}$ Department of Mechanical Engineering, Faculty of Engineering, Bayero University, Kano State, Nigeria.
}

Corresponding Author’s email: iayola.mec@buk.edu.ng

\begin{abstract}
This research investigated the environmental effect of local production methods of aluminium utensils in Bachirawa, Ungogo local government Kano. Three soil samples and two samples of water were collected from sites A, B,C, D and E. The samples were then taken to faculty of agriculture for analysis. Atomic absorption spectrophotometer (A A S model No 240 FSAA) was used to determine the concentration levels of heavy metals in the samples. The results show that, the concentration levels of heavy metals in the soil samples A, B and C are: Zn ranges between (1158.13 - 11,117.80) $\mathrm{mg} / \mathrm{kg}$; $\mathrm{Mn}$ between (285.719 $1809.672) \mathrm{mg} / \mathrm{kg}$; Cd between $(0.026-0.540) \mathrm{mg} / \mathrm{kg}$; $\mathrm{Cr}(0.498-0.832) \mathrm{mg} / \mathrm{kg}$ and $\mathrm{Pb}$ between $(42.54-$ $285.53) \mathrm{mg} / \mathrm{kg}$. The observed concentration levels in water samples for $\mathrm{Zn}$ ranges between $(0.2411-$ $0.4435) \mathrm{mg} / \mathrm{l}$; Cd between $(0.091-0.123) \mathrm{mg} / \mathrm{l}$; Cr between $(0.015-0.022) \mathrm{mg} / \mathrm{l}$; Mn between $(0.284-$ $0.728) \mathrm{mg} / \mathrm{l}$ and $\mathrm{Pb}$ between (0.00-0.08) $\mathrm{mg} / \mathrm{l}$. Zinc and Manganese have higher concentration levels than the recommended permissible limit set by European Union (EU) and United Kingdom(UK) while Cd, Cr and $\mathrm{Pb}$ have lower concentration levels than the recommended permissible limit set by EU and UK in soil samples $\mathrm{A}, \mathrm{B}$ and $\mathrm{C}$. The concentration levels of $\mathrm{Mn}, \mathrm{Cd}$ and $\mathrm{Pb}$ in water samples were higher than the permissible limit set by World Healh Organization (WHO) whereas $\mathrm{Zn}$ and $\mathrm{Cr}$ have concentrations lower than the recommended permissible limit set by WHO. Generally, the values of $\mathrm{Zn}, \mathrm{Mn}, \mathrm{Cd}, \mathrm{Pb}$ and $\mathrm{Cr}$ obtained from the sites were higher than the control sites. The contamination/pollution index revealed that the soil was in a state of moderate to excessive pollution. Drinking water directly from the sites can be deleterious to the people.
\end{abstract}

Keywords: Pollution; Utensils, Absorption, Concentration, Spectrophotometer, Permissible.

\section{INTRODUCTION}

The third most abundant element in the earth's crust a part from oxygen and silica is aluminum (Patricia, 2000). Bauxite is a rock that consists of one or more aluminum hydroxide minerals and is the principle raw material used in the production of alumina by the aluminum industries. Gibbsite $\left\{\mathrm{Al}(\mathrm{OH})_{3}\right\}$, boehmite $\{\mathrm{AlO}(\mathrm{OH})\}$ and mixed bauxite (gibbsite and boehmite) are the bauxites used in the production of aluminum metals (Patricia, 2000). Some of the properties that attract many industries in using aluminum are light weight, corrosion resistance, formability and high strength-toweight ratio (Tan and Khoo, 2004). Metal casting technique was known to have been practiced in the middle belt of Nigeria through iron melting during the NOK culture. Iron smelting was also known to be in practice in Kano City over 1000 years ago. Bronze castings were made on the South-West of Benin, Ife and Egboukwu for over 1000 years in the city of Benin (Khan, 2005). Basic tools were locally manufactured by artisans; iron ore was mined and smelted around Ajaokuta, Kogi State and Ojirtami in Edo State before colonization. These include basic agricultural tools, surgical tools, domestic tools and military tools. Foundry technology is one of the vital bases for industrial development of any nation (Shuaib-Babata et. al., 2017). Sand is used in making moulds for casting metals of different sizes and is found to be relatively cheap and adequate for use in foundry industry (Shuaib-Babata et. al.,
2017). Researchers had discovered through their studies that most Nigerian moulding sands were suitable for foundry application (Abolarin, 2004; Tokan, 2004 and Shuaib-Babata, 2014). Solid state or direct recycling of aluminium reduces the amount of fund spend on environmental protection and energy consumption than the conventional recycling by smelting (Shazarel et. al., 2016). The energy spend in secondary aluminium production is about $10 \mathrm{GJ} /$ tons of the material which is $5-10 \%$ of the energy in the primary aluminum output(Güley et. al., 2010). Land is polluted with both solid and liquid materials, these include: agricultural wastes, metals, rubbers, plastics, woods, grease, oil, etc. Such pollutants cause serious problems to the environment and to human beings. Heavy metal contamination in soil is a major concern because of their toxicity and threat to human life and environment (Begum et.al., 2009). Toxic heavy metals entering ecosystem may lead to geo-accumulation, bio-accumulation and magnification (Suciu, et. al, 2008). Researchers have asserted that due to the absorptive properties of the soil, some pollutants such as $\mathrm{Cd}, \mathrm{Pb}, \mathrm{Fe}, \mathrm{Cr}$, and $\mathrm{Zn}$ have long lives in soils and food grown on such polluted soils (Lickens, 2004). These environmental problems are influenced by industries such as foundries. The objective of this research is to access the environmental effect associated with the local production method of aluminium utensils in Bachira, Ungogo local Area of Kano State. 


\section{Casting}

Metal casting process begins by creating a mould and is made from a refractory material, for example, sand. The metal is heated in an oven until it melts and the molten metal is poured into the mould cavity. After the molten metal solidifies in the cavity, the part is then remove from the mould and finally clean.(Ekundayo, 2003). In sand casting process, moulds are formed by ramming sand onto a pattern. The pattern is then removed which leaves a cavity in the sand and the cavities are made with sand cores. Molten metal is poured into the mould and after it has solidified the mould is broken to remove the casting. Sand casting is a versatile and low cost process using a wide range of alloys. Sand castings do not give accurate dimensions compared to other casting processes and have a relatively poor surface finish (Lenka, 2010). Die casting is commonly used for permanent mould casting process. It is used for producing components of home appliances such as; rice cookers, stoves, fans, washing and drying machines, etc. The surface finish and tolerance of die cast parts is good and does not require any post-processing. Die casting moulds are expensive and require significant time to fabricate.

\section{Local Production of Aluminum Utensils in Bachirawa:}

Alhaji Sunusi and Sons Company, Bachirawa Ungoggo local government, Kano state, Nigeria involved in the production of local cooking pots, frying pans and spoons of various sizes using Aluminum scraps. Melting of the Aluminum scrap is carried out in a local melting furnace. The local furnace consists of a cast iron crucible which is placed in the combustion chamber and then heated by charcoal (source of fuel). The combustion chamber is lined with red clay which serves as the refractory material. Heat is supplied to the furnace from the bottom by a combination of an electric motor, a fan and a duct system. The sources of aluminium scraps are vehicles, metal products for construction, cables and wires, electrical and electronic equipment and packaging (Lenka 2010). Figure 1 shows an example of the products from Alhaji Sunusi and Sons Company Bachirawa Ungoggo local government, Kano state, Nigeria.

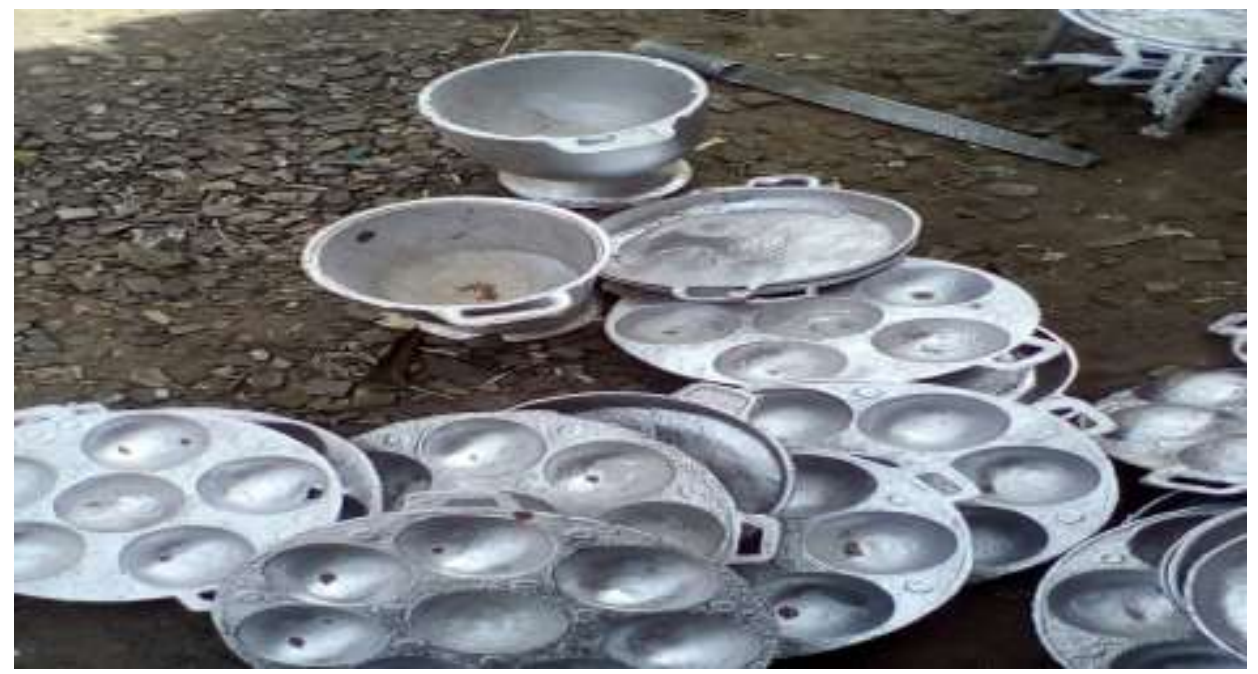

Fig. 1: Samples of locally made Aluminium products for making fried cake "Waina"

\section{MATERIALS AND METHODS \\ Materials/Equipment}

Atomic absorption spectrophotometer Model No 240FSAA ; Weigh Balance; Electric Hot Plate; Nitric acid $\left(\mathrm{HNO}_{3}\right) ; 70 \%$ solution of Perchloric acid $\left(\mathrm{HClO}_{4}\right) ; 5 \%(\mathrm{w} / \mathrm{v})$ Lanthanum solution ; Watch glass; Fume Cupboard; Berzelius Beaker; Acetylene Gas.

\section{METHODS}

Study area:

Ungogo local government Area is one of the forty-four local government areas of Kano state Nigeria with an estimated population of 367,657 people and land mass of $204 \mathrm{~km}^{2}$. It is located between latitude $12^{\circ} 05^{\prime} 26^{\prime \prime} \mathrm{N}$ and longitudes $8^{\circ} 29^{\prime} 48^{\prime \prime}$ E. It's headquarter is located at the north of an ancient city of Kano. The indigenes are (Hausa and Fulani) and their main occupation is farming, trading, and rearing of animals. The main crops grown in the local government are guinea corn, millet, maize and beans. Ungoggo local government area is shearing border with six local governments namely; Kumbotso, Dawakin Tofa, Dala, Nassarawa, and Minjibir. 


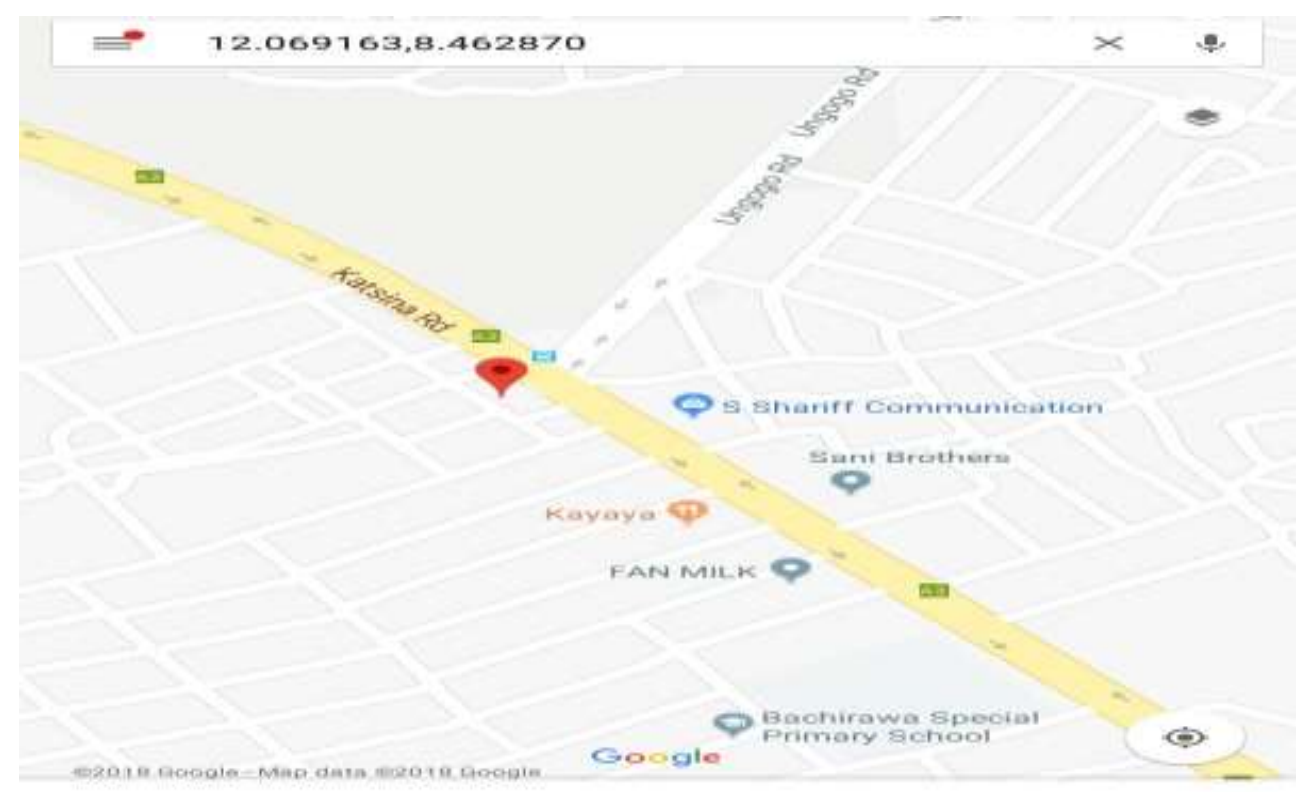

Fig.2 Map of the study area showing Bachirawa, Ungogo Local Government, Kano state Nigeria

\section{Samples collection}

\section{Soil samples}

Three sampling sites for soil were selected. $1 \mathrm{~kg}$ of sample was collected at each sampling site and the control site at a depth of $18 \mathrm{~cm}$ each using a spade. The samples were taken from 50 , 100 and $150 \mathrm{~m}$ away from production site and then labeled as samples A, B \& C. The soil samples were grounded using pestle and mortar, dried and sieved through $2 \mathrm{~mm}$ size. They were then taken to Faculty of Agriculture Laboratory, Bayero University Kano for heavy metal content analysis.

\section{Water samples}

Two samples of water labeled D and E were collected in $75 \mathrm{cl}$ bottles from boreholes $50 \mathrm{~m}$ away from the project site and then taken to Faculty of Agriculture Laboratory, Bayero University Kano for heavy metal content analysis.

\section{Determination of heavy metal in the soil samples}

One gramme $(1 \mathrm{~g})$ of dried and sieved soil sample form site A, site $\mathrm{B}$, site $\mathrm{C}$ and control site was collected at each site. The samples and a blank were digested with $5 \mathrm{ml}$ of concentrated nitric acid $\left(\mathrm{HNO}_{3}\right)$ and $2 \mathrm{ml}$ of $70 \%$ Perchloric acid $\left(\mathrm{HCIO}_{4}\right)$. Each beaker was covered with a watch glass and the digestion was carried out on a hot plate in a fume chamber until it's colour turned white. The digestion continued until the entire volume was reduced to about $15 \mathrm{ml}$. The digestion was allowed to cool to room temperature and then filtered. The mixture was diluted with $5 \mathrm{ml}$ of $20 \%$ Nitric acid. Atomic absorption spectrophotometer Model No 240FSAA was used to analyze the samples extract (ASTM, 1981).

\section{Determination of heavy metals in the water samples}

$50 \mathrm{ml}$ of each sample was acidified with $20 \mathrm{ml}$ of nitric, hydrochloric and perchloric acid. The mixture was digested on a hot plate in a fume chamber for one hour at $100^{\circ} \mathrm{C}$ until clear solution was seen and the volume reduces to $20 \mathrm{ml}$ with presence of white fumes. The mixture was filtered with filter paper after cooling and transferred to $100 \mathrm{ml}$ plastic bottle.
Deionized water was added into the bottle up to $50 \mathrm{ml}$ mark. Atomic Absorption Spectrophotometer (AAS) was used to analyze samples (Dauda, 2011).

\section{Quantification of Heavy Metal Contamination/Pollution Index}

The level of contamination in the soil samples was determined using the quantification of contamination/pollution index (MPI) of metals in soil adopted by Lacatusu (2000).

$M P I=\frac{\text { Concentration of metals in soil }}{\text { Reference soil }(\text { control site })}$

MPI gives the ranges between soil contamination and soil pollution. This index represents the ratio between the concentration of heavy metal content measured in soil by chemical analysis and reference value obtained from the control soil. The values of contamination/pollution index of soil greater than $1(>1)$ gives the pollution range and those less than $1(<1)$ gives the contamination range. The two ranges were divided into interval of $<0.1$ as very slight contamination, $0.10-0.25$ as slight contamination, $0.26-0.5$ as moderate contamination, $0.51-0.75$ as severe contamination, $0.76-1.00$ as very severe contamination, $1.1-2.0$ as slight pollution, 2.1 4.0 as moderate pollution, $4.1-8.0$ as severe pollution, $8.1-$ 16.0 as very severe pollution and $>16.0$ as excessive pollution. No negative effect on soil, plant and environment from very slight contamination $(<0.1)$ to very severe contamination $(0.76$ $1.00)$ but from slight pollution $(1.1-2.0)$ to excessive pollution $(>16.0)$ there is negative effect on soil, plant and environment (Lacatusu, 2000).

\section{RESULTS AND DISCUSSION}

\section{Results}

Tables 1-3 present the contamination/pollution levels caused by heavy metals in the soil samples. Table 4 presents concentration levels of heavy metals in water when compared with the permissible limits set by World Health Organization (WHO). Table 5 presents the Maximum permissible limits for heavy metals in soil. Figure 3 presents the graph of 
concentration levels of heavy metals in the soil samples while figure 4 presents the concentration levels of heavy metals in water samples.

Table1: Contamination/pollution index for heavy metals in site $A$ at $18 \mathrm{~cm}$ depth

\begin{tabular}{|c|c|c|c|c|c|c|}
\hline $\begin{array}{l}\text { Heavy } \\
\text { Metals }\end{array}$ & Depth & $\begin{array}{l}\text { Concentration of } \\
\text { metals in soil } \\
\text { sample A }(\mathrm{mg} / \mathrm{kg})\end{array}$ & $\begin{array}{l}\text { Concentration of } \\
\text { metals in control } \\
\text { site }(\mathrm{mg} / \mathrm{kg})\end{array}$ & MPI & $\begin{array}{l}\text { Class interval } \\
\text { According to } \\
\text { Lacatusu (2000) }\end{array}$ & Significance \\
\hline $\mathrm{Zn}$ & $18 \mathrm{~cm}$ & 11117.80 & 10.966 & 1013.84 & $>16.0$ & $\begin{array}{l}\text { Excessive } \\
\text { pollution }\end{array}$ \\
\hline $\mathrm{Cd}$ & $18 \mathrm{~cm}$ & 0.540 & 0.004 & 135 & $>16.0$ & $\begin{array}{l}\text { Excessive } \\
\text { pollution }\end{array}$ \\
\hline $\mathrm{Cr}$ & $18 \mathrm{~cm}$ & 0.498 & 0.127 & 3.92 & $2.1-4.0$ & $\begin{array}{l}\text { Moderate } \\
\text { pollution }\end{array}$ \\
\hline Mn & $18 \mathrm{~cm}$ & 420.49 & 22.011 & 19.10 & $>16.0$ & $\begin{array}{l}\text { Excessive } \\
\text { pollution }\end{array}$ \\
\hline $\mathrm{Pb}$ & $18 \mathrm{~cm}$ & 285.59 & 1.863 & 153.46 & $>16.0$ & $\begin{array}{l}\text { Excessive } \\
\text { pollution }\end{array}$ \\
\hline
\end{tabular}

Table 2: Contamination/pollution index for heavy metals in site $B$ at $18 \mathrm{~cm}$ depth

\begin{tabular}{|c|c|c|c|c|c|c|}
\hline $\begin{array}{l}\text { Heavy } \\
\text { Metals }\end{array}$ & Depth & $\begin{array}{l}\text { Conc. of } \\
\text { metals in soil } \\
\text { sample B } \\
(\mathrm{mg} / \mathrm{kg})\end{array}$ & $\begin{array}{l}\text { Conc. of } \\
\text { metals in } \\
\text { control site } \\
(\mathrm{mg} / \mathrm{kg})\end{array}$ & MPI & $\begin{array}{l}\text { Class interval } \\
\text { according to } \\
\text { Lacatusu (2000) }\end{array}$ & Significance \\
\hline $\mathrm{Zn}$ & $18 \mathrm{~cm}$ & 10118.44 & 20.124 & 502.8 & $>16.0$ & Excessive pollution \\
\hline $\mathrm{Cd}$ & $18 \mathrm{~cm}$ & 0.026 & 0.108 & 0.24 & $0.26-0.5$ & $\begin{array}{l}\text { Moderate } \\
\text { Contamination }\end{array}$ \\
\hline $\begin{array}{l}\mathrm{Cr} \\
\mathrm{Mn}\end{array}$ & $\begin{array}{l}18 \mathrm{~cm} \\
18 \mathrm{~cm}\end{array}$ & $\begin{array}{l}0.636 \\
1809.672\end{array}$ & $\begin{array}{l}0.100 \\
10.672\end{array}$ & $\begin{array}{l}6.36 \\
169.57\end{array}$ & $\begin{array}{l}4.1-8.0 \\
>16.0\end{array}$ & $\begin{array}{l}\text { Severe pollution } \\
\text { Excessive pollution }\end{array}$ \\
\hline $\mathrm{Pb}$ & $18 \mathrm{~cm}$ & 42.54 & 3.751 & 11.34 & $8.1-16.0$ & $\begin{array}{l}\text { Very Severe } \\
\text { Pollution }\end{array}$ \\
\hline
\end{tabular}

Table 3: Contamination/pollution index for heavy metals in site $\mathrm{C}$ at $18 \mathrm{~cm}$ depth

\begin{tabular}{|c|c|c|c|c|c|c|}
\hline $\begin{array}{l}\text { Heavy } \\
\text { Metals }\end{array}$ & Depth & $\begin{array}{l}\text { Conc. } \\
\text { metals in soil } \\
\text { sample C } \\
(\mathrm{mg} / \mathrm{kg})\end{array}$ & $\begin{array}{l}\text { Conc. of } \\
\text { metals in } \\
\text { control site } \\
(\mathrm{mg} / \mathrm{kg})\end{array}$ & MPI & $\begin{array}{l}\text { Class interval } \\
\text { According to } \\
\text { Lacatusu (2000) }\end{array}$ & Significance \\
\hline
\end{tabular}

\begin{tabular}{|c|c|c|c|c|c|c|}
\hline $\mathrm{Zn}$ & $18 \mathrm{~cm}$ & 1158.132 & 20.266 & 57.15 & $>16.0$ & Excessive pollution \\
\hline $\mathrm{Cd}$ & $18 \mathrm{~cm}$ & 0.165 & 0.048 & 3.43 & $2.1-4.0$ & Moderate pollution \\
\hline $\mathrm{Cr}$ & $18 \mathrm{~cm}$ & 0.832 & 0.131 & 6.35 & $4.1-8.0$ & Severe pollution \\
\hline $\mathrm{Mn}$ & $18 \mathrm{~cm}$ & 285.719 & 13.061 & 21.88 & $8.1-16.0$ & $\begin{array}{l}\text { Very Severe } \\
\text { Pollution }\end{array}$ \\
\hline $\mathrm{Pb}$ & $18 \mathrm{~cm}$ & 148.19 & 4.24 & 34.91 & $>16.0$ & Excessive pollution \\
\hline
\end{tabular}


Table 4: Concentration $(\mathrm{mg} / \mathrm{l})$ of heavy metals in water samples

\begin{tabular}{|c|c|c|c|c|}
\hline $\begin{array}{l}\text { Sampling } \\
\text { Sites }\end{array}$ & $\begin{array}{l}\text { Heavy } \\
\text { metals }\end{array}$ & $\begin{array}{l}\text { Concentration } \\
\text { metals in } \\
\mathrm{mg} / \mathrm{l}\end{array}$ & of & $\begin{array}{l}\text { WHO(2008) } \\
\text { Guideline in } \\
\mathrm{mg} / \mathrm{l}\end{array}$ \\
\hline \multirow{5}{*}{ Site D } & $\mathrm{Zn}$ & 0.2411 & & 3.0 \\
\hline & $\mathrm{Cd}$ & 0.091 & & 0.003 \\
\hline & $\mathrm{Cr}$ & 0.015 & & 0.05 \\
\hline & $\mathrm{Mn}$ & 0.284 & & 0.4 \\
\hline & $\mathrm{Pb}$ & 0.00 & & 0.01 \\
\hline \multirow{5}{*}{ Site E } & $\mathrm{Zn}$ & 0.4435 & & 3.0 \\
\hline & $\mathrm{Cd}$ & 0.123 & & 0.003 \\
\hline & $\mathrm{Cr}$ & 0.022 & & 0.05 \\
\hline & $\mathrm{Mn}$ & 0.728 & & 0.4 \\
\hline & $\mathrm{Pb}$ & 0.08 & & 0.01 \\
\hline
\end{tabular}

Table 5: Maximum permissible limits for heavy metals in soil

\begin{tabular}{|l|l|l|l|l|l|}
\hline $\begin{array}{l}\text { Heavy metals } \\
\mathrm{mg} / \mathrm{kg}\end{array}$ & $\begin{array}{l}\text { EU STD } \\
\mathrm{mg} / \mathrm{kg}\end{array}$ & $\begin{array}{l}\text { UK STD } \\
\mathrm{mg} / \mathrm{kg}\end{array}$ & $\begin{array}{l}\text { US STD } \\
\mathrm{mg} / \mathrm{kg}\end{array}$ & WHO mg/kg & $\begin{array}{l}\text { Ranges for uncontaminated soil } \\
(\mathrm{mg} / \mathrm{kg})(\text { Nageria, 2001) }\end{array}$ \\
\hline $\mathrm{Fe}$ & - & - & - & - & $7000-5500$ \\
\hline $\mathrm{Zn}$ & 300 & 200 & $200-300$ & $12-160$ & $10-300$ \\
\hline $\mathrm{Hg}$ & - & - & - & $0.001-0.04$ & $0.01-0.3$ \\
\hline $\mathrm{Cu}$ & 140 & 63 & $80-200$ & $1-12$ & $2-100$ \\
\hline $\mathrm{Cd}$ & 3.0 & 1.4 & 400 & $0.002-0.5$ & $0.01-0.7$ \\
\hline $\mathrm{Cr}$ & 180 & 6.4 & 400 & $0.002-0.2$ & $5-3000$ \\
\hline $\mathrm{Pb}$ & 300 & 70 & 300 & $0.3-10$ & $2-200$ \\
\hline $\mathrm{Ni}$ & - & - & - & $0.1-5$ & $10-1000$ \\
\hline
\end{tabular}

Source: $\quad$ Edieve,V. F. and Umoetok, B.A .(2017)

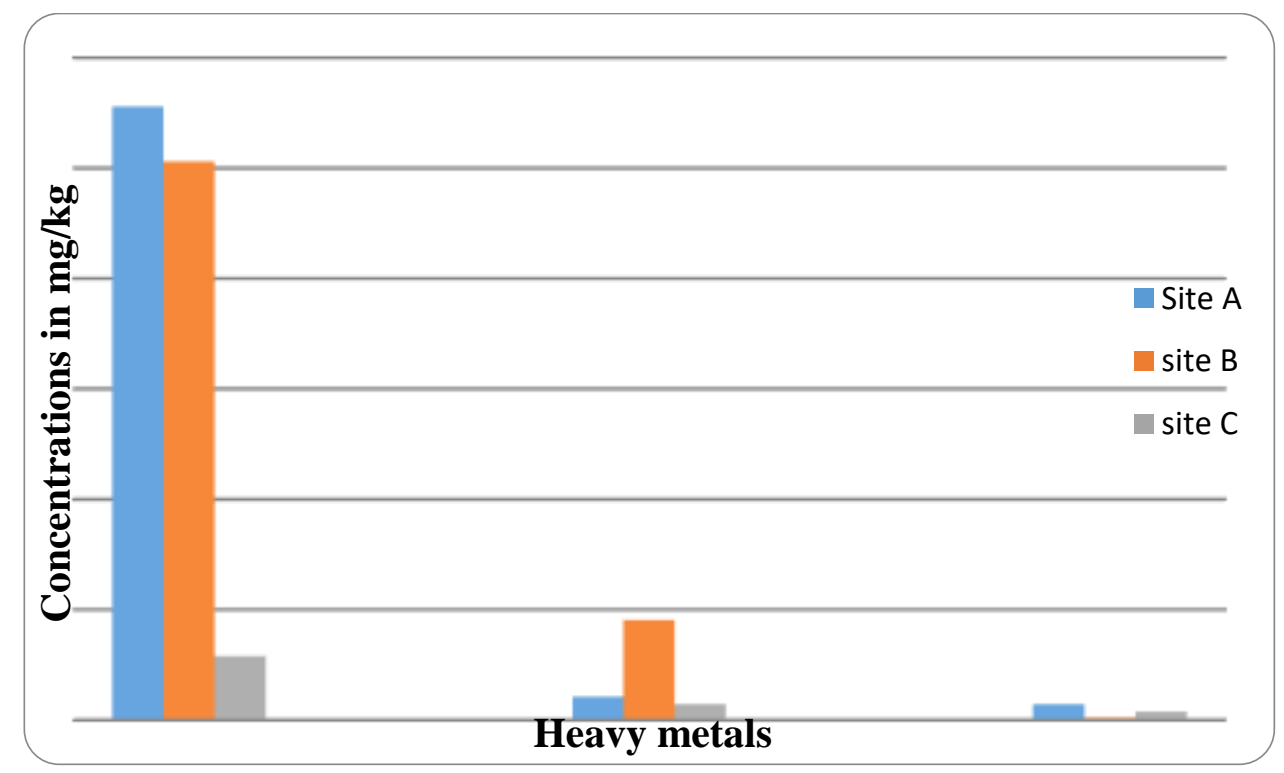

Figure 3: Concentration of heavy metals $(\mathrm{mg} / \mathrm{kg})$ in sites A, B and C 


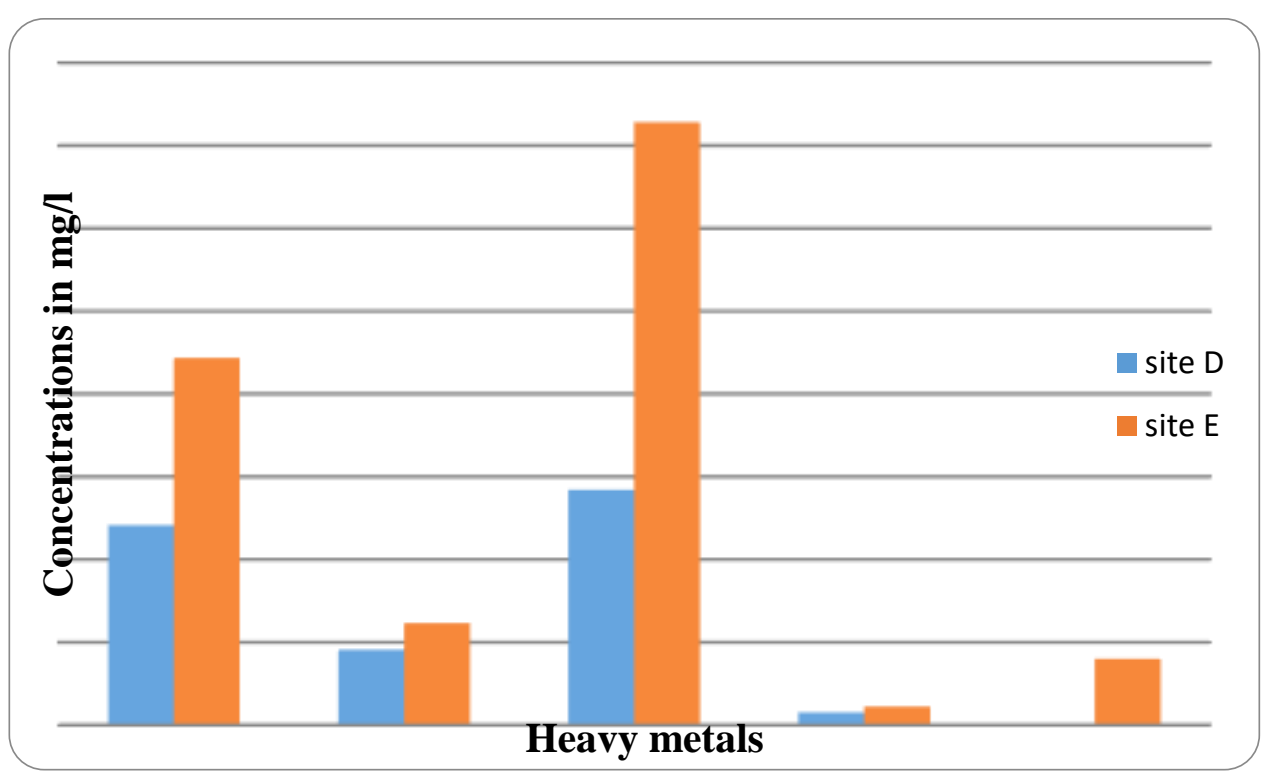

Figure 4: Concentration of heavy metals (mg/l) in sites D and E

\section{DISCUSSION OF RESULTS}

\section{Concentrations of heavy metals in Soil}

Zinc: $\mathrm{Zn}$ is the abundant metal detected in all the sites investigated. The concentrations of $\mathrm{Zn}$ are $11117.80 \mathrm{mg} / \mathrm{kg}, 10118.44 \mathrm{mg} / \mathrm{kg}$ and $1158.132 \mathrm{mg} / \mathrm{kg}$ for sites A, B and C respectively. The control sites recorded lower concentrations of $10.966 \mathrm{mg} / \mathrm{kg}, 20.124 \mathrm{mg} / \mathrm{kg}$ and $20.2266 \mathrm{mg} / \mathrm{kg}$ which indicated variations between the tested soils and the control sites. $\mathrm{Zn}$ concentrations in all the sites have exceeded the permissible limit of $300 \mathrm{mg} / \mathrm{kg}$ and $200 \mathrm{mg} / \mathrm{kg}$ set by E.U and U.K standards respectively. The contamination/pollution index shows that, the sites were excessively polluted with $\mathrm{Zn}$.

Cadmium: The concentration values of $\mathrm{Cd}$ examined in the soil at the sites A, B and C are $0.540 \mathrm{mg} / \mathrm{kg}, 0.026 \mathrm{mg} / \mathrm{kg}$ and $0.165 \mathrm{mg} / \mathrm{kg}$ respectively while the control sites have concentrations of 0.004 $\mathrm{mg} / \mathrm{kg}, 0.108 \mathrm{mg} / \mathrm{kg}$ and $0.048 \mathrm{mg} / \mathrm{kg}$. The concentration of $\mathrm{Cd}$ at sites $\mathrm{A}$ and $\mathrm{C}$ are higher than the concentration at site $\mathrm{B}$ while the concentration at the control site of $\mathrm{B}$ has the highest concentration value of $0.108 \mathrm{mg} / \mathrm{kg}$. The concentrations of Cd observed in all the sites are lower than permissi ble limit of $3.0 \mathrm{mg} / \mathrm{kg}$ and $1.4 \mathrm{mg} / \mathrm{kg}$ set by E.U and U.K. standards respectively. The contamination/pollution Index shows that, there was moderate contamination to excessive pollution of $\mathrm{Cd}$ in the sites.

Manganese: Manganese is the second available metal detected in the soil samples at the study area. The concentrations of Mn are 420.49 $\mathrm{mg} / \mathrm{kg}, 1809.672 \mathrm{mg} / \mathrm{kg}$ and $285.719 \mathrm{mg} / \mathrm{kg}$ for sites A, B and C respectively. The control sites recorded lower concentrations of $22.011 \mathrm{mg} / \mathrm{kg}, 10.672 \mathrm{mg} / \mathrm{kg}$ and $13.061 \mathrm{mg} / \mathrm{kg}$. The concentrations of $\mathrm{Mn}$ observed in all the sites are lower than the concentration recorded in all the control sites. The concentration of $\mathrm{Mn}$ recorded from the sites are higher than the concentration value of $79.03-$ $244.94 \mathrm{mg} / \mathrm{kg}$ reported by (Tahar and Okeltoum 2011) for heavy metal concentration in soil and plants in the industrial area. The contamination/pollution Index shows that, there was very severe to excessive pollution of $\mathrm{Mn}$ in the sites.
Chromium: The examined Concentration of $\mathrm{Cr}$ in the soil at sites A, $\mathrm{B}$ and $\mathrm{C}$ are $0.498 \mathrm{mg} / \mathrm{kg}, 0.636 \mathrm{mg} / \mathrm{kg}$ and $0.832 \mathrm{mg} / \mathrm{kg}$ respectively while the control sites have concentrations of $0.127 \mathrm{mg} / \mathrm{kg}, 0.100$ $\mathrm{mg} / \mathrm{kg}$ and $0.131 \mathrm{mg} / \mathrm{kg}$. The concentrations of $\mathrm{Cr}$ are higher than the concentrations recorded at the control sites. The mean concentrations $\mathrm{Cr}$ recorded from the sites are lower than the maximum permissible limit of $180 \mathrm{mg} / \mathrm{kg}$ and $6.4 \mathrm{mg} / \mathrm{kg}$ set by E.U. and U.K. standards respectively. The contamination/pollution Index shows that, there was moderate to severe pollution of $\mathrm{Cr}$ in the sites.

Lead: The concentrations of $\mathrm{Pb}$ are $285.59 \mathrm{mg} / \mathrm{kg}, 42.54 \mathrm{mg} / \mathrm{kg}$ and $148.19 \mathrm{mg} / \mathrm{kg}$ for sites A, B and C respectively while the control sites recorded lower concentrations of $1.863 \mathrm{mg} / \mathrm{kg}, 4.24 \mathrm{mg} / \mathrm{kg}$ and $13.061 \mathrm{mg} / \mathrm{kg}$. The concentrations of $\mathrm{Pb}$ observed in all the sites are higher than the concentration recorded in the control sites. The concentrations of $\mathrm{Pb}$ in the sites are lower than the standard permissible limit of $300 \mathrm{mg} / \mathrm{kg}$ set by E.U but higher than U.K standard with $70 \mathrm{mg} / \mathrm{kg}$. The contamination/pollution Index shows that, there was very severe pollution to excessive pollution of $\mathrm{Pb}$ in the study area.

\section{Concentrations of heavy metals in water}

The concentration of zinc obtained from water samples was higher in site D with $0.4435 \mathrm{mg} / \mathrm{l}$ and lower in site E with $0.2411 \mathrm{mg} / \mathrm{l}$. The concentrations of $\mathrm{Zn}$ in all the samples were observed to be below the maximum permissible limit of $3.0 \mathrm{mg} / \mathrm{l}$ set by WHO for drinking water.

The concentration of cadmium obtained from the sampling sites D and $\mathrm{E}$ are shown in figure 4 . The results have shown that, the highest concentration of $\mathrm{Cd}$ was recorded in site $\mathrm{E}$ with $0.123 \mathrm{mg} / \mathrm{l}$ and the lowest in site D with $0.091 \mathrm{mg} / \mathrm{l}$. The concentration of $\mathrm{Cd}$ in all the sites were higher than the maximum permissible limit of $0.003 \mathrm{mg} / \mathrm{l}$ set by the world health organization(WHO) for drinking water. Cadmium causes fibrosis, respiratory diseases, hypertension and also affects the nerves system.

The concentrations level of Manganese $(\mathrm{Mn})$ obtained from the 
sampling sites are presented in figure 4. The concentration of $\mathrm{Mn}$ recorded was higher in site $\mathrm{E}$ with $0.728 \mathrm{mg} / \mathrm{l}$ and lower in site D with $0.284 \mathrm{mg} / \mathrm{l}$. The concentrations of $\mathrm{Mn}$ were higher than the maximum permissible limit of $0.1 \mathrm{mg} / 1$ set by the world health organization (WHO) for drinking water.

The concentrations of chromium in the sites are presented in figure 4. Site E has the highest concentration of chromium with $0.022 \mathrm{mg} / \mathrm{l}$ and site D has the lowest with $0.015 \mathrm{mg} / \mathrm{l}$. The concentration of chromium in all the sites were observed to be below the maximum permissible limit of $0.1 \mathrm{mg} / 1$ set by the world health organization (WHO) for drinking water.

The concentrations of $\mathrm{Pb}$ obtained from the sampling sites $\mathrm{D}$ and $\mathrm{E}$ are presented in figure 4 . The highest concentration of $\mathrm{Pb}$ was recorded in site E with $0.08 \mathrm{mg} / 1$ while the lowest was recorded in site $\mathrm{D}$ with $0.00 \mathrm{mg} / \mathrm{l}$. The results show that, there was $\mathrm{Pb}$ in site $\mathrm{E}$ and site $\mathrm{D}$ has no $\mathrm{Pb}$. The concentration of $\mathrm{Pb}$ in site $\mathrm{E}$ was higher than the maximum permissible limit of $0.05 \mathrm{mg} / \mathrm{l}$ set by WHO (2008) for drinking water. Therefore, drinking water from site E may cause toxicity to the central and peripheral nervous system, cancer, and can affect mental development in infant WHO (2008).

\section{CONCLUSION}

The study revealed that foundry activities are also sources of environmental pollution in Bachirawa foundry market. It was found that, the concentrations of heavy metals in decreasing order are as follows: $\mathrm{Zn}>\mathrm{Mn}>\mathrm{Pb}>\mathrm{Cd}>\mathrm{Cr}$. Zinc, Manganese, lead and Cadmium were the major soil pollutants in the study area. The results obtained from water samples have showed that, the concentrations of $\mathrm{Cd}$ and $\mathrm{Mn}$ in all the sites and $\mathrm{Pb}$ in site $\mathrm{E}$ were above the permissible limit set by $\mathrm{WHO}(2008)$, therefore, drinking water directly from the sites can be deleterious to the people.

\section{REFERENCES}

Abolarin, M.S.,Olughoji, O.A. and Ugwkoke, I. C.(2004). Experimental Investigation on Local Refractory Materials for Furnace Construction. Procedure of the $5^{\text {th }}$ Annual Engineering Conference, Federal University of Technology, Minna, Nigeria. Pp $82-85$

ASTM D3974(1981). Standard Practices for Extraction of Trace Elements from Sediments. ASTM International Barr Harber Drive, West Conshohocken, United States, PP393-395

Begum, A., Ramaiah, M., Irfanulla, K. and Veena, K.(2009). Analysis of heavy metal concentrations in soil and Litchens from various localities of Hosur Road Bangalore, India. CONDENFCJHAO, E.J.Chem. 6(1); 13-22.

Dauda, A. (2011). An Introduction to Atomic Absorption Spectrophotometry. Omo-Ojo Print and Publishers Nig. Coy, Lagos Nigeria. pp.11-24.

Ekundayo, G. (2003). Foundry Technology for Mechanical Students, Bosem Publisher Akure. Pp. 61-64.

Edieve,V. F. and Umoetok, B.A.(2017).Concentration of Heavy Metals in Soils at the Municipal Dumpsites in Calabar Metropolis. Asian Journals of Environment and Ecology. 3(2): 1-11.
Güley, V., Khalifa, N. and Tekkaya, A. E.(2010). Direct recycling of 1050 aluminium alloy scrap material mixed with 6060 aluminium alloy chips by hot extrusion. International Journal of Material Forming. 3: 853-856

Lacatusu., R. (2000)." Appraisal levels of Soil Contamination and Pollution with Heavy Metals

In Soil". European Soil Research Report, No 4 office of official publication of the European Communities, L.uxembourg,pp.393402.

Lenka, M. and Peter, E. (2010)." End-of-waste Criteria for Aluminum and Aluminum Alloy Scrap", European Commission, Joint Research Centre, Institute for Prospective Technological Studies. pp. 1-59.

Lickens, G. E. (2004). Effluent Monitoring Journal for Shell Petroleum Development Company of Nigeria Ltd East 22, 1-28

Khan, R.H.(2005) "Metal Casting Technology In Nigeria - Present Status and future Prospects".22 pp.7-13

Patricia, A.P.(2000). Aluminum Recycling in the United States. U. S. Geological Survey Circular 1196-W. pp; 1-6

Shazarel,S., Lajis, M.A. and Zhong, Z.W.(2016).Evolutionary in Solid State Recycling Techniques of Aluminium: A review. $13^{\text {th }}$ Global Conference on Sustainable Manufacturing-Decoupling Growth fron Resource Use.Procedia CIRP 40; 256-261

Shuaib-Babata, Y. L. and Olumodeji, J.O.(2014). Analysis of Ilorin Sand Moulding Properties for Foundry Application. International Journal of Engineering Research and Technology (IJERT). 3(1);1520-1526.

Shuaib-Babata, Y. L.,Abegunde, A. J. and Abdul, J.M.(2017). Suitability of Ado-Ekiti(Nigeria)Natural Moulding Sands for use as Foundry Sands in Production of Aluminium Alloy cast. Journal of Production Engineering. 20(2): 91-100.

Suciu, I., Cosma, C., Todica, M., Bolbaca, S.D. and Jantschi, L.(2008). Analysis of Soil heavy metal pollution and pattern in central Transylvania. International Journal of Mol. Science. 9: 434453.

Tan, R.B.H. and Khoo, H.H.(2004). An LCA Study of a primary aluminum supply chain. Journal of clear production. ELSEVIER pp 1-12. doi:10.1016/j.jclepro.

Tokan, A., Adelemoni, E.A. and Datau, S.G.(2004). Mould Characteristics of Azare Foundry Sand. Journal of raw materials research. (JORMAR). 1(1): 67-78

WHO (2008). World Health Organisation, Guidelines for drinking water quality, World Health Organisation Geneva. pp. 113-154 